\title{
Tipologi Fasad Hunian Pengrajin Tempe Koridor Jalan Sanan Malang
}

\author{
Rahadian Nugroho \\ Jurusan Arsitektur, FT-UB \\ Jl. Mayjen Haryono 167 Malang 65145
}

\section{Abstrak}

Kata Kunci : Tipologi Fasad, Kerajinan Tempe, Tradisi Budaya, Jalan Sanan Malang

Hunian masyarakat pengrajin tempe di Kampung Sanan Malang merupakan hunian yang terbentuk dari penyesuaian budaya masyarakat tehadap globalisasi yang salah satunya berdampak terhadap ekonomi. Pada awalnya, hunian di kampung ini hanya digunakan untuk tempat tinggal, namun kemudian penduduk mulai menggunakan hunian mereka untuk memproduksi serta menjual tempe dan keripik tempe, dan saat ini Kampung Sanan telah menjadi sentra industri tempe. Kegiatan memproduksi tempe bagi masyarakat Kampung Sanan merupakan Budaya Lokal turun-temurun yang memungkinkan terjadinya perbedaan tipologi karakteristik fasad hunian masing-masing pengrajin tempe. Tujuan utama dari kajian ini adalah mendeskripsikan tipologi karakteristik fasad hunian masyarakat kampung Sanan Malang sesusai jenis usahanya dalam industri tempe. Metode yang digunakan dalam kajian ini adalah kualitatif deskriptif dengan pendekatan tipologi berdasar pada bukti empiris, tipomorfo, relasi fungsi, dan bentuk. Pengumpulan datanya dilakukan dengan pengambilan foto, video, wawancara mendalam dan observasi kemudian dianalisis untuk mendapatkan gambaran dan kesimpulan yang dapat menjawab permasalahan dan mencapai tujuan studi. Kesimpulan dari studi ini menyebutkan bahwa tipologi karakteristik fasad hunian masyarakat Kampung Sanan secara langsung dan tak langsung memunculkan identitas dan tradisi baru yang berjalan beriringan dengan tradisi yang lama. Perbedaan karakteristik fasad antar pengrajin tempe juga dipengaruhi oleh besar kecilnya omset masing-masing pengrajin.
\end{abstract}

\begin{abstract}
Residential society of tempe craftsmen community in Kampung Sanan Malang is a shelter formed from cultural adaptation tehadap globalization which one of them impact on economy. At first, the residential area of this village was only used for residence, but then the residents started to use their dwelling to produce and sell tempe and tempe chips, and now Kampung Sanan has become a tempe industry center. The activity of producing tempe for the society of Sanan Village is a hereditary Local Culture that allows the different typology of the facade characteristics of each tempe craftsman. The main objective of this study is to describe the typology of the facade characteristics of the Sanan Malang village community after the type of business in tempe industry. The method used in this study is qualitative descriptive with typology approach based on empirical evidence, tipomorpho, function relation, and form. Data collection is done by taking photos, videos, in-depth interviews and observation and then analyzed to get a picture and conclusion that can answer the problems and achieve the purpose of study. The conclusions of this study suggest that the typology of the facade characteristics of the Kampung Sanan community directly and indirectly bring new identities and traditions that go hand in hand with the old tradition. Differences in the facade characteristics among tempe craftsmen are also influenced by the small turnover of each craftsman.
\end{abstract}

Keywords:

Facade typology,

Tempe Craftsmen, Cultural Tradition, Sanan Village Malang 


\section{PENDAHULUAN}

\subsection{Latar Belakang}

Hampir setiap bangunan dalam kurun waktu tertentu akan mengalami perubahan baik langsung maupun tidak langsung, berubah akibat adanya proses adaptasi untuk menghadapi perubahan kebutuhan di tiap-tiap generasi ataupun karena faktor ekonomi. Perubahan ini terjadi karena adanya perubahan peradaban, perubahan spirit zaman dan perubahan dari era lama ke era baru, misalnya dari era pertanian ke era industri, sehingga kemapanan secara ekonomis tentu berubah dan pada akhirnya berujung pada sebuah kebutuhan perubahan yang berimbas pada bangunan. Dalam hubungan ini 2 elemen Budaya perlu diidentifikasi secara cermat. Elemen pertama adalah Inti Budaya yang menolak untuk berubah. Lainnya adalah elemen Budaya yang mampu berubah, tumbuh dengan cepat tetapi perlu didorong untuk mampu menghadapi tantangan dari luar tanpa kehilangan jiwa roh jati dirinya.

Jati diri atau identitas merupakan "jejak" yang ditinggalkan oleh peradaban, bergerak sejalan dengan sejarah dan merupakan sebuah "proses" yang tidak terjadi dengan sendirinya tetapi bertolak dari logika yang dikuti oleh masyarakatnya. Jati diri lahir dan tumbuh dari pengertian terhadap diri sendiri, dan masyarakat lingkungannya (Wiranto, 1999:17).

Bertambahnya jumlah keluarga tentu saja akan menambah jumlah kebutuhan dalam memenuhi keperluan anggota keluarga itu sendiri semakin meningkat. Kebutuhan keluarga ini akan terasa ringan terpenuhi jika ada usaha yang mendatangkan income atau penghasilan keluarga untuk menutupi kebutuhan tersebut. Home Industri yang pada umumnya berawal dari usaha keluarga yang turun menurun dan pada akhirnya meluas ini secara otomatis dapat bermanfaat menjadi mata pencaharian penduduk kampung di sekitarnya. Kegiatan ekonomi ini biasanya tidak begitu menyita waktu, sehingga memungkinkan pelaku usaha membagi waktunya untuk keluarga dan pekerjaan tetap yang ditekuni.

Bagi masyarakat Kampung Sanan, hunian sangat erat kaitannya dengan usaha tempe karena usaha ini sudah ada sejak tahun 1900an dan dilakukan secara turun temurun. Fungsi hunian tidak hanya untuk memenuhi kebutuhan dasar seharihari tapi juga sebagai alat untuk memenuhi kebutuhan perekonomian mereka. Hunian dipandang sebagai modal usaha untuk meningkatkan pendapatan penghuni dan kesejahteraannya melalui usaha industri rumah tangga yang memproduksi tempe dan keripik tempe.

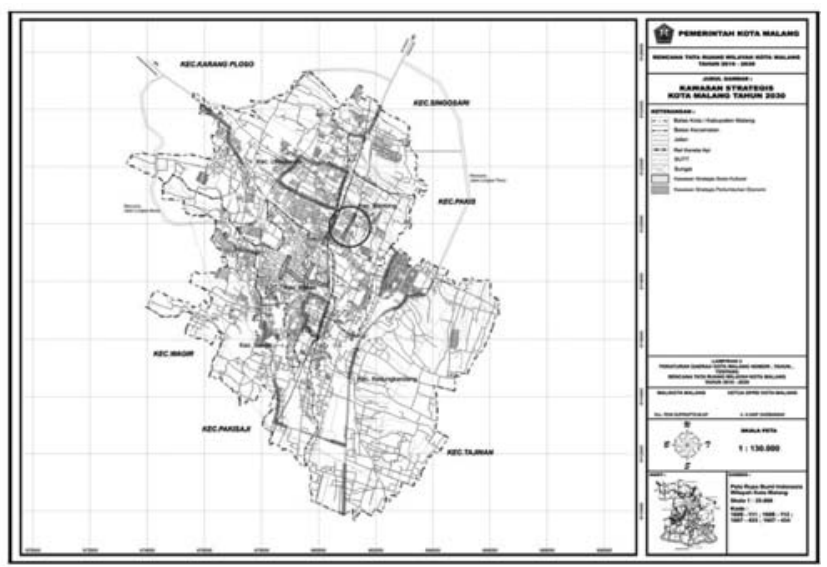

Kawasan Strategis Kota Malang tahun 2010-2030

Kampung Sanan yang terletak di Kelurahan Purwantoro memiliki kedudukan yang penting bagi Kota Malang. Saking pentingnya, pada waktu kampanye pilpres 2009 beberapa saat yang lalu, Kampung Sanan merupakan tempat yang dijadikan daerah kunjungan calon presiden SBY. Keistimewaan Kampung Sanan terletak pada adanya industri kecil yang berkembang di sana. Produk yang dihasilkan dari industri tersebut adalah tempe dan keripik tempe. Produk ini sangat terkenal tidak hanya di Kota Malang tapi juga diluar kota bahkan luar negeri. Bagi wisatawan yang datang ke Kota Malang, keripik tempe merupakan produk yang 


\section{Tipologi Fasad Hunian Pengrajin Tempe Koridor Jalan Sanan Malang \\ Rahadian Nugroho}

dicari untuk dijadikan oleh-oleh. Industri kecil tersebut dikategorikan industri rumah tangga karena memanfaatkan hunian sebagai tempat berproduksi. Saat ini terdapat kurang lebih 600 kepala keluarga yang menggantungkan penghidupannya di bidang produksi tempe ini dengan 286 kepala keluaga terdaftar di Primer Koperasi Produsen Tempe Tahu Indonesia (Primkopti) Bangkit Usaha Kota Malang. Kampung Sanan ditetapkan sebagai sentra industri tempe oleh warga Kampung Sanan dengan mendirikan gapura di depan pintu masuk kampung dimana pada gapura tersebut ditulis Sentra Industri Tempe Sanan.

\subsection{Permasalahan}

Pada penelitian ini proses interaksi antara penghuni dan huniannya di Kampung Sanan akan dicoba untuk dikenali dan ditemukan dengan melihat pada pola perubahan pada fasadenya jika memang mengalami perubahan. Turner (1972) berpendapat bahwa penghuni akan melakukan "tindakan" untuk memenuhi kebutuhannya ketika penghuni merasakan kekurangan pada huniannya. Tindakan itu dapat berupa adaptasi dan dapat pula berupa melakukan perubahan yang masing-masing akan memunculkan konflik-konflik tertentu. Selain itu Habraken (1973) menyatakan bahwa selain ruang, bagian hunian yang sering dilakukan perubahan adalah pada bagian fasadenya. Penghuni di Kampung Sanan diyakini juga melakukan "tindakan" yang diperlukan saat ada fungsi kerja dalam huniannya, yang perlu diidentifikasikan adalah tindakan yang penghuni lakukan, sehingga pertanyaanya adalah bagaimanakah tipologi karakteristik fasad hunian pengrajin tempe yang berada di Kampung Sanan Malang?

Kajian ini hanya meneliti/mengkaji tipologi karakteristik fasad hunian pengrajin tempe di sepanjang koridor jalan Sanan saja. Tidak termasuk hunian pengrajin di dalam gang-gang atau jalanjalan kecil di wilayah Kampung Sanan Malang.

\subsection{Tujuan}

Tujuan dari penelitian ini adalah untuk mengidentifikasi pengaruh usaha dalam rumah tangga terhadap fasad hunian pengrajin tempe. Kemudian juga mengidentifikasi faktor-faktor apa saja yang mempengaruhi pola perubahan fasad pada masing-masing hunian pengrajin tempe di Kampung Sanan Malang.

\section{DASAR ANALISIS}

\subsection{Deskripsi Kawasan}

Berdirinya Kampung Sanan diperkirakan sudah lama sekali, dimana keberadaan awal kampung ini ditandai dengan adanya makam tua yaitu Makam Buyut Kibah yang diyakini sebagai pembuka lahan pertama kali, dan sampai saat ini (masih dihormati oleh penduduk Kampung Sanan. Pekerjaan utama penduduk Sanan pada waktu itu diyakini adalah bertani karena sampai saat ini masih terdapat sisa-sisa lahan pertanian.

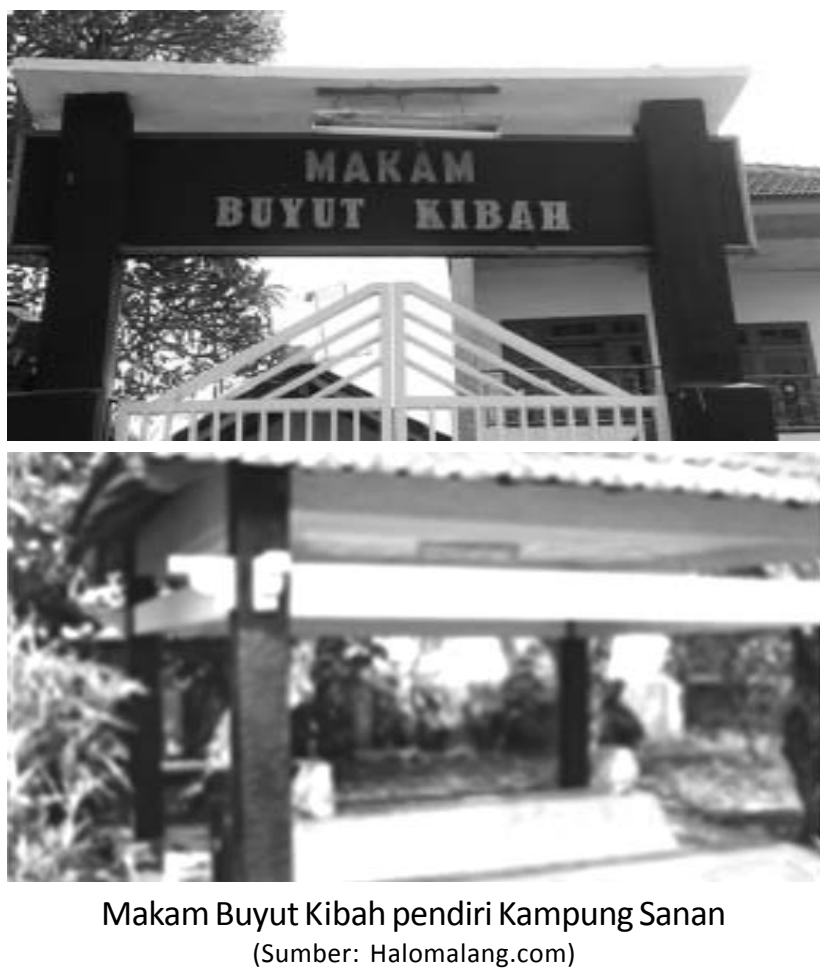


Sebagai penghasil tempe, Kampung Sanan telah dikenal sejak tahun 1900-an (tanggal dan tahun pastinya tidak jelas sama dengan awal berdirinya kampung ini karena tidak ada lagi nara sumber yang bisa menginformasikannya). Sebelum tahun 1970-an warga Kampung Sanan hanya memproduksi tempe saja, yang dipasarkan ke semua pasar di Kota Malang dan Kabupaten Malang. Dalam perkembangannya hingga sekarang, penduduk Kampung Sanan melakukan variasi usaha dengan memproduksi keripik tempe. Ide pembuatan keripik tempe berawal dari banyaknya tempe yang dijual terbuang karena tidak laku. Tempetempe sisa tersebut kemudian dicoba untuk dibuat keripik yang ternyata laku dijual di pasaran.

Kampung Sanan yang memiliki luas $\pm 20 \mathrm{Ha}$ ini, terletak di Kota Malang, Kelurahan Purwantoro, Kecamatan Blimbing, yaitu meliputi RW 14 (4 RT), RW 15 (9 RT) dan RW 16 (9 RT) dengan jumlah kepala keluarga seluruhnya \pm 660 keluarga, dan yang tergabung pada koperasi (Primkopti Bangkit Usaha) berjumlah \pm 300 kepala keluarga.
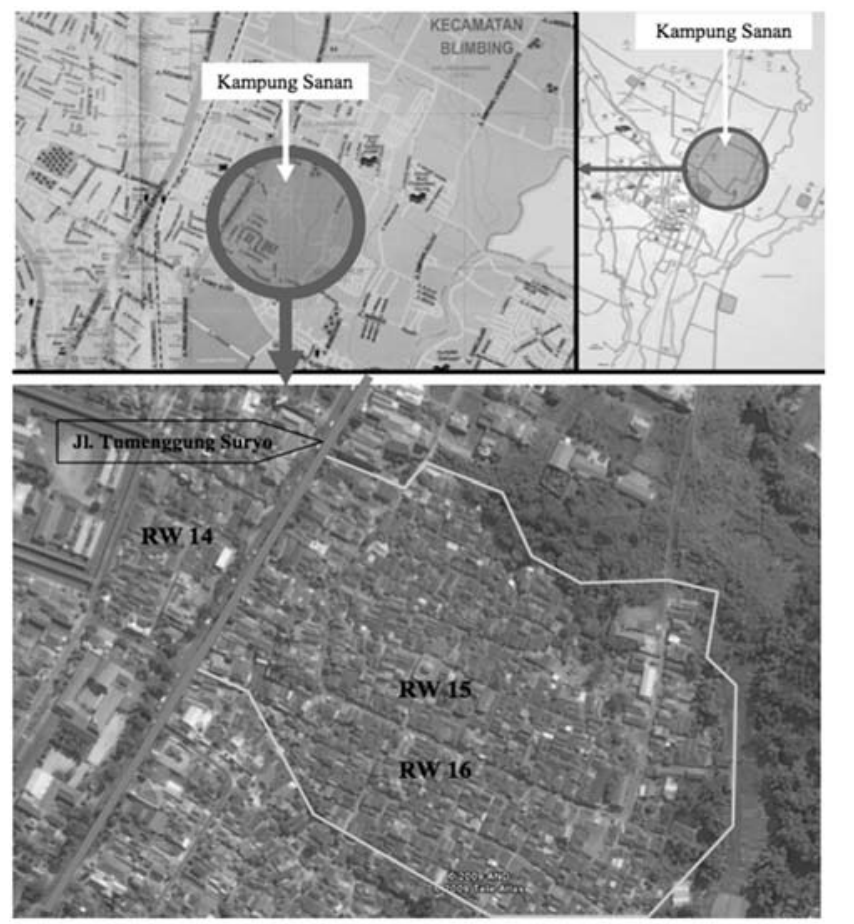

Citra Satelit Kampung Sanan (Sumber: Google, 2016)
Pada awalnya, Kampung Sanan baik RW 14, RW 15 dan RW 16 merupakan satu wilayah yang utuh namun sejak dibangunnya Jalan Tumenggung Suryo (dibuat untuk memudahkan jalur transportasi dari Surabaya sampai ke pusat Kota Malang) yang membelah kampung ini sehingga ketiga RW tersebut terpisah dimana RW 14 di sebelah barat dan RW 15 serta RW 16 berada di sebelah timur Jalan Tumenggung Suryo.

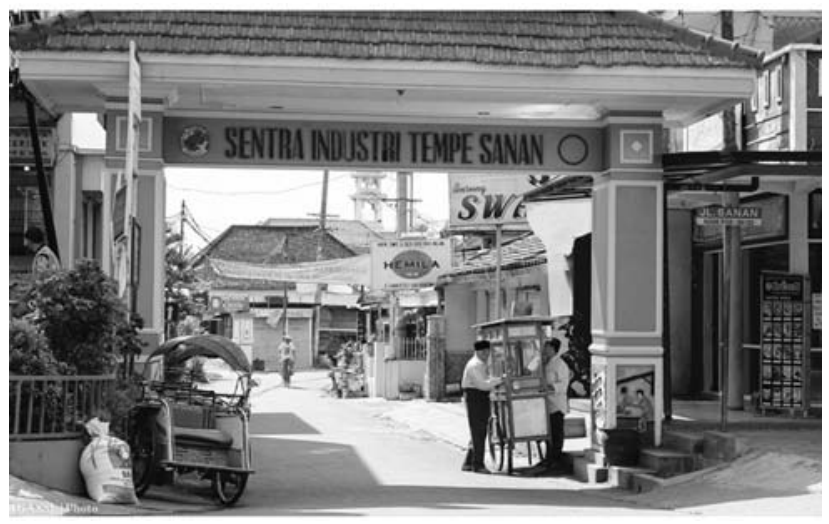

Gerbang masuk Kampung Sanan (Sumber: Google, 2016)

Kondisi jalan masuk utama kampung sendiri sangat baik dengan diaspal oleh pemerintah daerah demikian juga dengan kondisi jalan masuk ke ganggang dalam kampung dimana warga berinisiatif untuk membuat perkerasan baik itu dengan semen maupun memasang paving stone. Kondisi saluran pembuangan di samping kiri dan kanan jalan baik jalan utama maupun gang-gang cukup baik dengan sebagian besar saluran merupakan saluran tertutup. Jalan akses menuju ke Kampung Sanan juga relatif mudah karena lokasi Kampung Sanan berada di tengah Kota Malang. Jalan akses ke Kampung Sanan dapat melalui Jl. Tumenggung Suryo maupun Jl. Sunandar Priyo Sudarmo. 

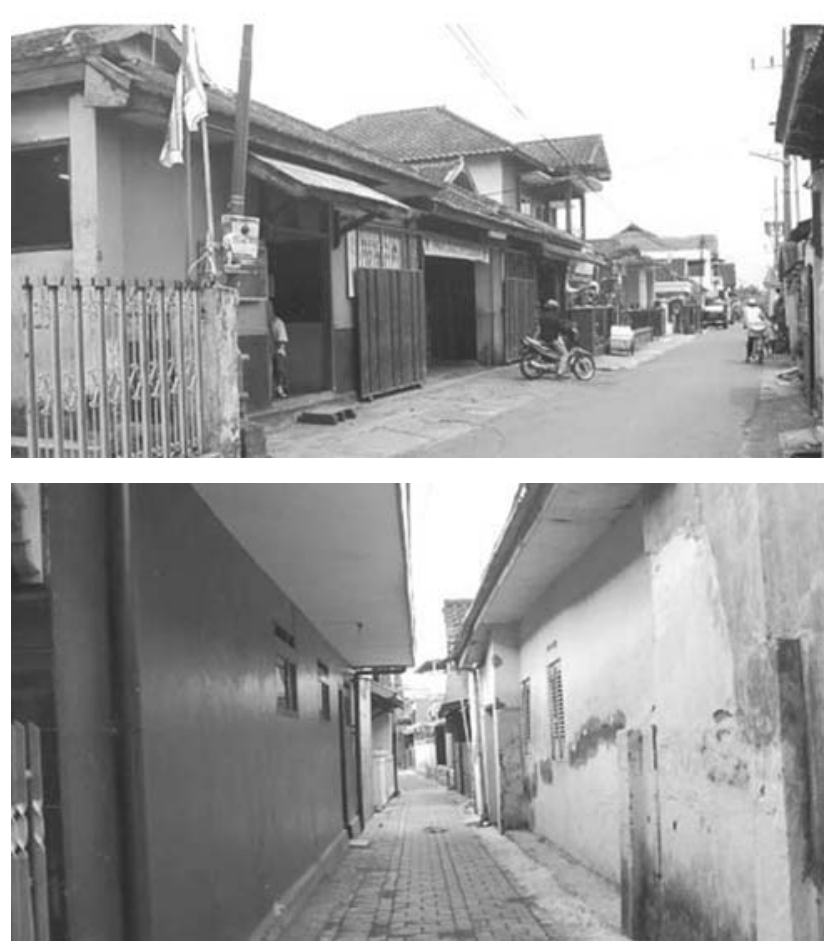

Jalan utama Kampung Sanan dan Jalan/ gang di dalam kampung

Kampung Sanan selain memiliki sarana dan prasarana yang cukup lengkap seperti rumah ibadah dan sekolah untuk tingkat dasar, juga dekat dengan sarana pendidikan lainnya hingga tingkat SMA bahkan akses menuju perguruan tinggipun cukup mudah, selain itu juga dekat dengan fasilitas sosial lainnya seperti Rumah Sakit Lavalette, lapangan olahraga Rampal, dan lain-lain. Juga dekat dengan sarana hiburan seperti pusat pertokoan Plasa Araya. Adanya jalan Tumenggung Suryo juga memudahkan akses pemasaran produk tempe baik dalam kota seperti ke pasar-pasar tradisional seperti Pasar Besar, Blimbing, Gadang, dan lainnya, maupun ke luar kota seperti Sidoarjo dan Surabaya apalagi Terminal Arjosari yang merupakan terminal antar kota sangat mudah diakses dari kampung ini.
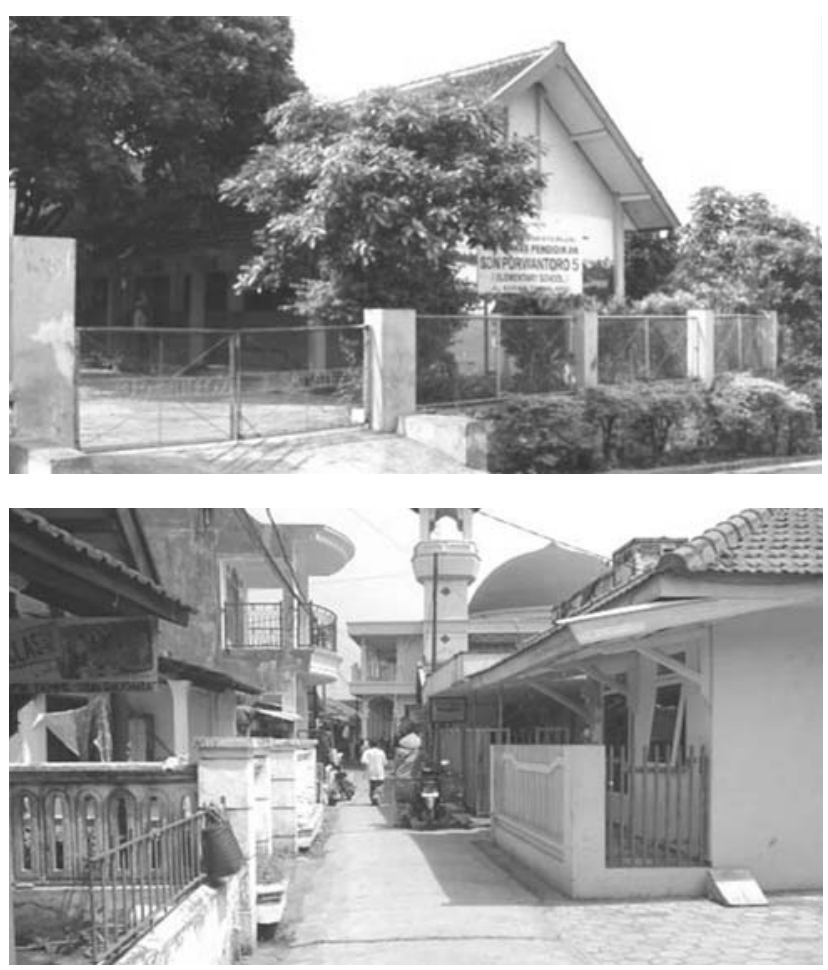

Sarana pendidikan dasar dan Sarana peribadatan

Sarana lain yang ada di Kampung Sanan adalah Koperasi Primkopti Bangkit Usaha yang berdiri sekitar tahun 1980an, dimana tujuan dari koperasi ini adalah membantu pengrajin dalam menjalankan dan mengembangkan usahanya. Koperasi ini selain menyediakan bahan baku dan peralatan juga memberi fasilitas simpan pinjam dan penyewaan kandang sapi bagi warga yang beternak sapi tapi tidak mempunyai kandang sendiri dengan biaya sewa 200 ribu pertahun.

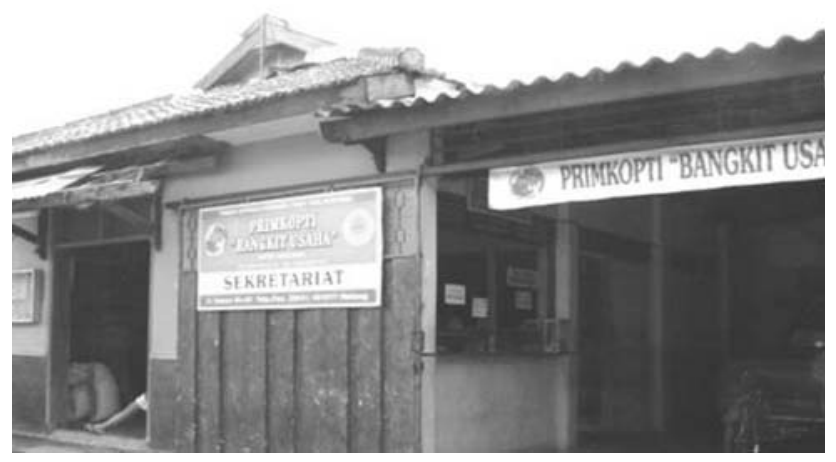




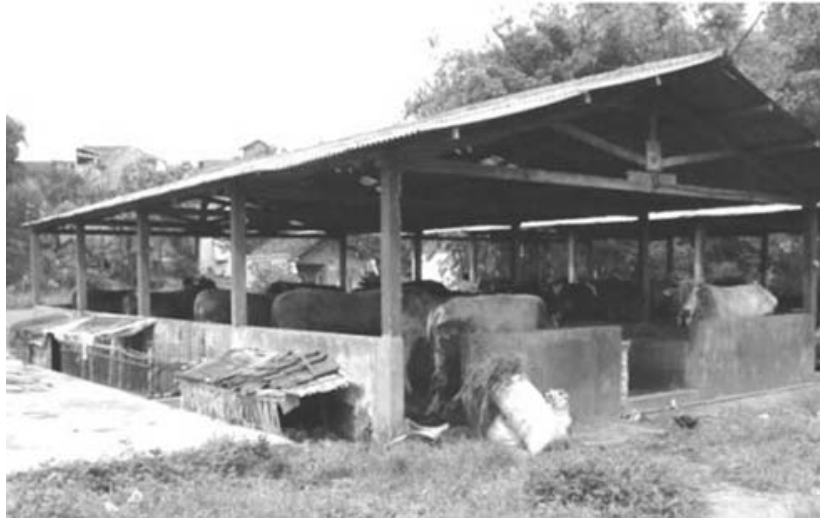

Primkopti Bangkit Usaha dan Kandang sapi milik Primkopti yang dapat disewa oleh Warga

Kampung Sanan terbagi atas 3 RW yaitu RW 14, RW 15, dan RW 16. Namun berdasarkan informasi dari Primkopti, di RW 14 hampir tidak ada lagi pengrajin tempe, populasi terbesar pengrajin tempe di Kampung Sanan ada di RW 15 dan RW 16. Di Kampung Sanan tidak ada pembagian lokasi yang jelas berdasarkan bidang klasifikasi usahanya, semuanya menyebar sehingga kualitas hunian yang baik dengan yang kurang baik bercampur jadi satu. Kualitas hunian dalam satu kualifikasi belum tentu sama. Namun berdasarkan hasil observasi biasanya hunian yang memiliki kualitas lebih baik mempunyai bidang usaha yang lebih beragam dan rata-rata berusaha dibidang keripik tempe.

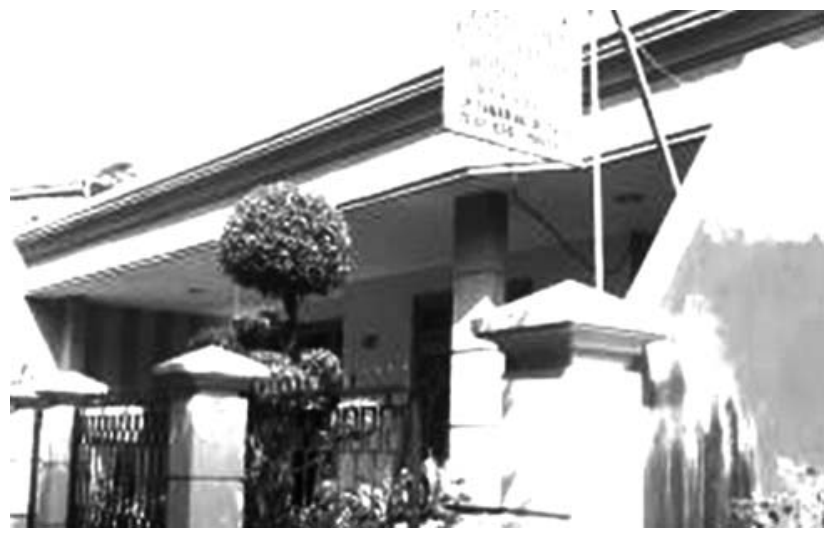

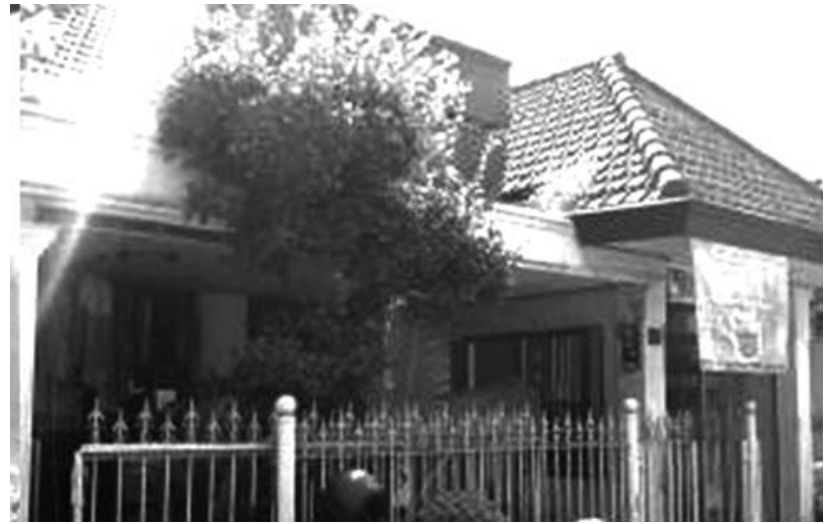

Hunian pengrajin tempe dan keripik di Kampung Sanan

Berdasarkan data Kecamatan Blimbing Kotamadya Malang, luas hunian di Kampung Sanan yang terbanyak antara 50-99 m2 (42\%) dan ada pula yang memiliki luas di atas $100 \mathrm{~m} 2$ sebanyak $32 \%$. Walaupun kepemilikan hunian terbesar adalah warisan dan milik sendiri (93\%) namun masih banyak hunian yang memiliki luas kurang dari 50 $\mathrm{m} 2$ sebanyak $26 \%$, kemungkinan usahanya tidak berkembang atau hasil usahanya tidak dikembalikan pada huniannya tapi diinvestasikan pada yang lain.

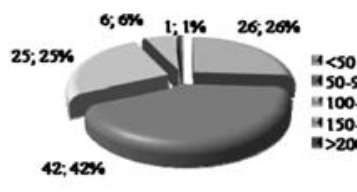

Luas Hunian sekarang

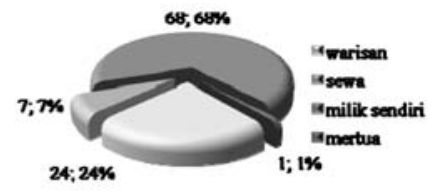

Status Kepemilikan Hunian
Di Kampung Sanan tidak ada pembagian lokasi yang jelas berdasarkan bidang klasifikasi usahanya, semuanya menyebar di seluruh kampung. Berdasarkan Monografi Kelurahan Purwantoro bulan Juli-Desember 2016, secara umum tingkat kepadatan di Kelurahan Purwantoro dimana Kampung Sanan berada di dalamnya adalah $1 \mathrm{~km} /$ jiwa. Berdasarkan hasil data Kecamatan, terlihat 


\section{Tipologi Fasad Hunian Pengrajin Tempe Koridor Jalan Sanan Malang \\ Rahadian Nugroho}

bahwa hunian di Kampung Sanan walau terdapat usaha rumah tangga tapi tidak padat $(66 \%)$. Jika melihat jenis keluarga terbesar yang ada di Kampung Sanan adalah keluarga inti (73\%) maka hal ini wajar karena jumlah anggota keluarga yang sedikit. Selain itu dimungkinkan pula karena pekerja tidak tidur di tempat kerja karena masih saudara atau tetangga yang sama-sama tinggal di Kampung Sanan. Dalam suatu keluarga jika anak-anaknya sudah dewasa maka akan memiliki hunian sendiri yang biasanya juga berlokasi di Kampung Sanan. Tingkat kepadatan yang tinggi dimungkinkan pada saat sedang berproduksi/jam kerja dimana pekerja baik anggota keluarga maupun tetangga yang tidak tinggal di hunian tersebut datang untuk bekerja. Hal ini biasanya terjadi pada hunian yang memproduksi keripik tempe dan membuka toko/ showroom.

\subsection{Budaya Masyarakat Kampung Sanan}

Masyarakat di kota Malang sendiri lebih familiar dengan menyebut salah satu sentra industri di kota Malang ini sebagai Kampung Sanan. Sejak berpuluh tahun yang lalu, Kampung Sanan menjadi pusat pembuatan tempe yang terkenal di kota Malang. Masyarakatnya sendiri cukup bangga dengan predikat sebagai pembuat tempe terbaik di kota Malang, sehingga mereka yakin bahwa tempe Sanan adalah salah satu ciri khas kota Malang di bidang kuliner yang patut dibanggakan. Usaha kripik tempe sendiri berkembang di awal tahun 2000an. Pasca krisis moneter yang melanda bangsa Indonesia di tahun 1998, usaha kecil menengah menjadi pembangkit perekonomian Indonesia di kala itu, walaupun pengusaha kecil sendiri tidak mudah melakukannya. Pada awal berkembangnya usaha kripik tempe Sanan Malang, pengusaha yang memproduksi kripik tempe hanya sedikit, tetapi saat ini pengrajin dan penjual kripik tempe Sanan telah mencapai sekitar 60 orang dengan jumlah pekerja mencapai sekitar 250 orang di Kampung
Sanan atau sebanyak $40 \%$ dari total pengusaha di Kampung Sanan.

Proses pembuatan kripik tempe sendiri adalah manifestasi budaya dan kreatifitas yang diciptakan oleh masyarakat yang bermukim di perkampungan Sanan. Telah lama dikenal sebagai produsen tempe terbaik di Malang, maupun di Jawa Timur, tidak serta merta membuat para pengusaa tempe mendapatkan kemudahan dalam melakukan penjualan tempe-tempenya. Sehingga mereka harus memutar otak bagaimana menanggulangi kerugian atas tempe-tempe yang tidak laku tersebut. Seluruh proses pembuatan masih dilakukan dengan cara yang masih manual. Dikarenakan usaha kripik tempe sendiri masih dalam skala industri rumahan, pekerjanya rata-rata tak lebih dari 10 orang, dengan pemilik usaha yang masih turun tangan dalam pembuatan proses produksi.

Kekeluargaan dan gotong royong benarbenar terlihat di setiap aktivitas di dalam Kampung Sanan. Baik yang berhubungan dengan usaha kripik tempe yang dijalani maupun kehidupan keluarga sehari-hari. Sebagaimana contohnya adalah tetangga yang saling membantu dan bersikap toleran satu sama lain, mereka tidak akan segan untuk mengulurkan tangan kepada usaha kripik tempe tetangganya walaupun jenis usaha yang dilakukan sebenarnya adalah sama.

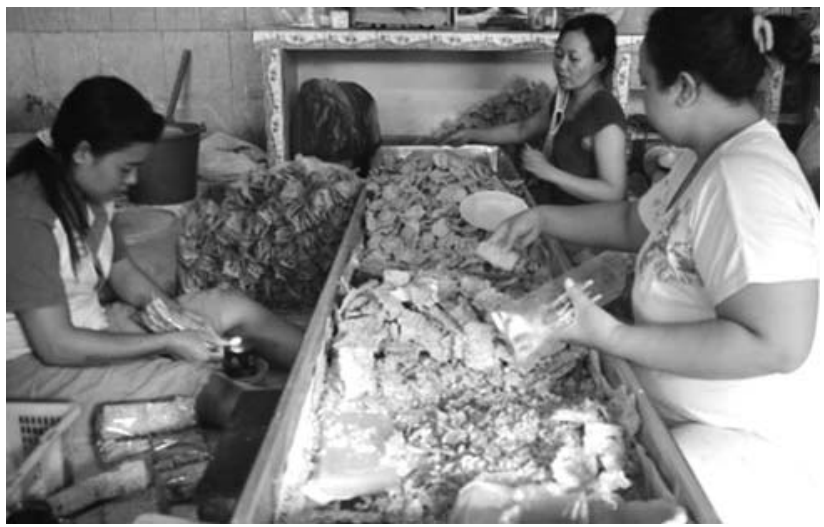

Gotong Royong Mengemas Keripik Tempe (Sumber: Google, 2016) 
Karakteristik selanjutnya adalah rasa rendah hati dan terbuka, dengan serta merta, penduduk di Kampung Sanan selalu terbuka menerima pengunjung dengan kerendahan hati yang membuat kesan ramah juga terasa dalam interaksinya. Mungkin dikarenakan pengunjung adalah berkah bagi mereka yang dapat membantu berkembangnya usaha mereka. Dapat dikatakan masyarakat di Sanan terbuka akan masukan dan mereka sadar bahwa perubahan akan memberikan efek bagi kehidupan maupun bisnis mereka.

Tetapi pada kenyataannya, masyarakat memiliki karakteristik yang akan membuat Kampung Sanana akan terus produktif. Kreatif dan Dinamis adalah karakteristik yang dimiliki oleh sebagian besar masyarakatnya; walaupun tingkat pendidikan sebagian besar orang dewasa di Kampung Sanan adalah SMA/SMK dan sederajat, tetapi dikarenakan karakteristik mereka yang terbuka, sehingga informasi dan perkembangan jaman yang dinamis membuat kreatifitas turut berkembang di masyarakatnya. Hal tersebut dibuktikan dengan bagaimana kripik tempe berawal dan berkembang hingga menjadi saat ini. Kampung Sanan yang menjadi pusat pengolahan tempe kedelai sejak bertahun-tahun yang lalu turut berkembang dan bertahan mengikuti perubahan jaman yang dinamis.

\subsection{Kajian Pustaka}

Berdasarkan ruang lingkupnya ruang publik dapat dibagi menjadi beberapa tipologi (Carmona, et al ,2003) antara lain:

1. External public space.

Ruang publik ini berbentuk ruang luar yang dapat diakses oleh semua orang seperti taman kota, alun-alun, jalur pejalan kaki, dan lain sebagainya.

2. Internal public space.

Ruang publik ini berupa sebuah bangunan fasilitas umum yang dikelola pemerintah dan dapat diakses oleh warga secara bebas tanpa ada batasan tertentu, seperti kantor pos, kantor polisi, dan pusat pelayanan warga lainnya.

3. External and internal "quasi" public space.

Ruang publik ini berupa fasilitas umum yang dikelola oleh sektor privat dan ada batasan atau aturan yang harus dipatuhi warga, seperti mall, restoran dan lain sebagainya.

Faqih (1997) dalam Prijotomo dan Santosa (1997) menjelaskan secara arsitektural bahwa tipologi adalah suatu kegiatan untuk mempelajari tipe dari objek-objek arsitektural, dan mengelompokkannya (menempatkan objek-objek tersebut) dalam suatu klasifikasi tipe berdasarkan kesamaan/ keserupaan dalam hal-hal tertentu yang dimiliki objek arsitektural tersebut. Kesamaan tersebut dapat berupa:

- Kesamaan bentuk dasar/sifat-sifat dasar sesuai dengan bentuk dasar objek tersebut.

- Kesamaan fungsi objek-objek tersebut

- Kesamaan asal-usul/perkembangan dan latar belakang sosial masyarakat objek tersebut berada, termasuk gaya atau langgam.

Menurut Sulistijowati (1991:12), pengenalan tipologi akan mengarah pada upaya untuk mengkelaskan, mengelompokkan atau mengklasifikasikan berdasar aspek atau kaidah tertentu. Aspek tersebut antara lain:

1). Fungsi (meliputi penggunaan ruang, struktural, simbolis, dan lain-lain);

2). Geometrik (meliputi bentuk, prinsip tatanan, dan lain-lain); dan

3). Langgam (meliputi periode, lokasi atau geografi, politik atau kekuasaan, etnik dan budaya, dan lain-lain).

Komposisi suatu façade, dengan mempertimbangkan semua persyaratan fungsionalnya (jendela, pintu, sun shading, bidang atap) pada prin- 


\section{Tipologi Fasad Hunian Pengrajin Tempe Koridor Jalan Sanan Malang \\ Rahadian Nugroho}

sipnya dilakukan dengan menciptakan kesatuan yang harmonis dengan menggunakan komposisi yang proporsional, unsur vertikal dan horisontal yang terstruktur, material, warna dan elemenelemen dekoratif. Hal lain yang tidak kalah penting untuk mendapatkan perhatian yang lebih adalah proporsi bukaan-bukaan, tinggi bangunan, prinsip perulangan, keseimbangan komposisi yang baik, serta tema yang tercakup ke dalam variasi (Krier 1988:72). Menurut Krier (1988:78) elemenelemen arsitektur pendukung façade, yaitu sebagai berikut:

A. Pintu

Pintu memainkan peranan yang menentukan dalam menghasilkan arah dan makna yang tepat pada suatu ruang. Ukuran umum yang digunakan adalah perbandingan proporsi 1:2 atau 1:3. Ukuran pintu selalu memiliki makna yang berbeda, misalnya pintu berukuran pendek untuk masuk ke dalam ruangan yang lebih privat. Posisi sebuah pintu dapat dipengaruhi oleh fungsi, bahkan pada batasan-batasan tertentu, yang memiliki keharmonisan geometris dengan ruangan tersebut.

B. Jendela

Beberapa hal yang harus diperhatikan dalam penataan jendela façade, yaitu sebagai berikut:

- Proporsi geometris façade;

- Penataan komposisi;

- Memperhatikan keharmonisan proporsi geometri;

- Karena distribusi jendela pada façade, salah satu efek tertentu dapat dipertegas atau bahkan dihilangkan; dan

- Jendela dapat bergabung dalam kelompok-kelompok kecil atau membagi façade dengan elemen-elemen yang hampir terpisah dan membentuk simbol tertentu.

Tipe jendela dapat diklasifikasikan ke dalam satu atau kombinasi dari beberapa tipe dasar terutama dalam hubungannya dengan peng- aturan aliran udara. Jendela dibagi ke dalam empat kategori, yaitu sebagai berikut:

a. Tipe putar, horisontal dan vertikal;

b. Tipe gantung, gantung samping, atas, bawah;

c. Tipe lipat; dan

d. Tipe sorong/geser, vertikal dan horizontal.

C. Dinding

Penataan dinding juga dapat diperlakukan sebagai bagian seni pahat sebuah bangunan. Bagian khusus dari suatu bangunan dapat diekspos dengan latar depan dan latar belakang dapat ditentukan

D. Atap

Atap merupakan mahkota bangunan yang disangga badan bangunan, yaitu dinding.

E. Sun Shading

Fasad beradaptasi dengan cuaca karena adanya ornamen di atas tembok, yaitu teritisan atau biasa disebut sun shading.

Menurut Lippsmeier (1980:74-90) elemen façade dari sebuah bangunan yang sekaligus merupakan komponen-komponen yang mempengaruhi fasade bangunan adalah:

1. Atap;

2. Dinding; dan

3. Lantai.

Elemen-elemen yang diperhatikan dalam meneliti fasade bangunan pada antar unit bangunan menurut Ardiani (2009) sebagai berikut:

1. Proporsi fasade

a. Proporsi bukaan, lokasi pintu masuk, ukuran pintu, jendela yang mengatur artikulasi rasio solid void pada dinding

b. Bahan bangunan permukaan material dan tekstur untuk menghasilkan motif batangan

c. Warna 
2. Komposisi massa bangunan

a. Tinggi bangunan untuk menciptakan skala yang tepat dengan bangunan sekitar dan skala manusia.

b. Garis sempadan bangunan depan dan samping yang mengatur jarak kemunduran bangunan dari jalan dan bangunan eksisting

c. Komposisi bentuk massa

3. Lain-lain
a. Langgam arsitektur
b. Penataan landscape

\section{HASIL DAN PEMBAHASAN}

Berdasarkan keterangan ketua RT setempat, populasi di Kampung Sanan terdiri dari beberapa lapisan/bagian, yang dapat diklasifikasikan sebagai berikut:

1) Hunian dengan tempat produksi tempe mentah.

2) Hunian dengan tempat produksi keripik tempe.

3) Hunian dengan tempat produksi tempe dan keripik tempe.

4) Hunian dengan tempat produksi tempe, keripik tempe dan membuka toko/showroom.

5) Hunian dengan tempat pengemasan/ packaging keripik tempe.

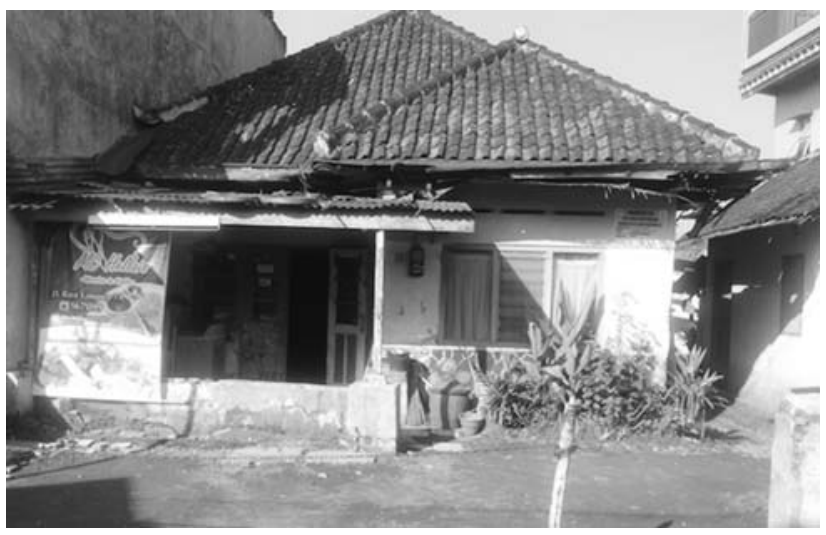

Hunian dengan tempat produksi tempe mentah

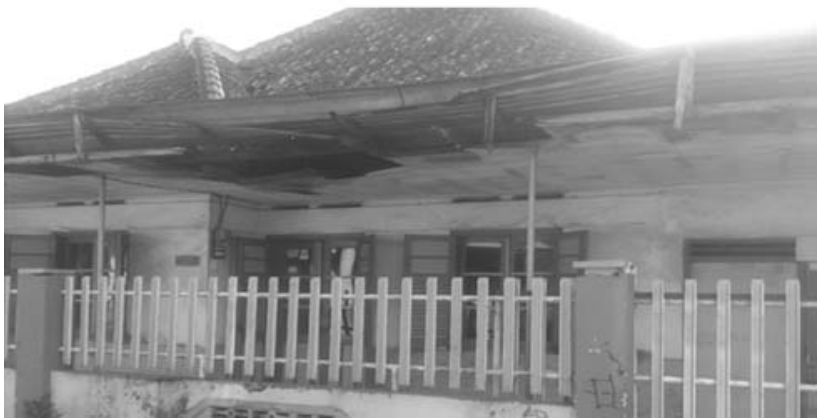

Hunian dengan tempat produksi keripik tempe

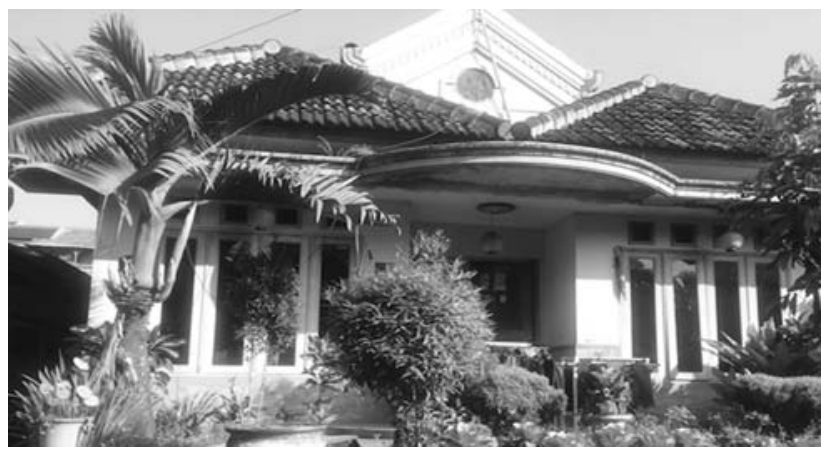

Hunian dengan tempat produksi tempe dan keripik tempe

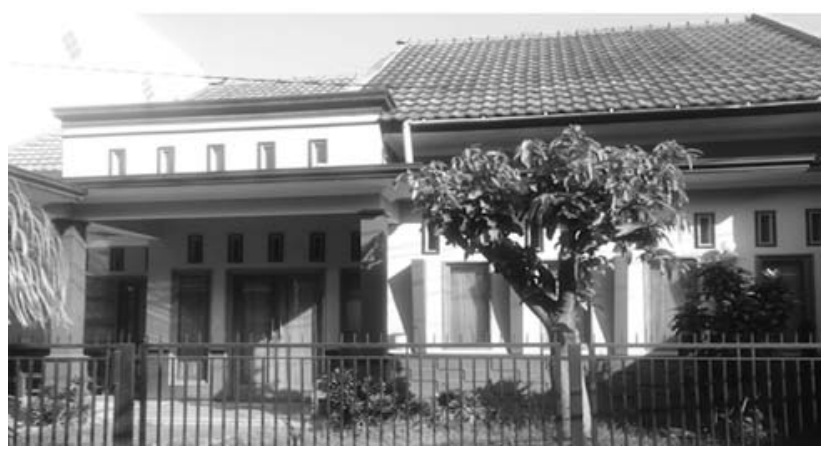

Hunian dengan tempat produksi tempe, keripik tempe dan membuka toko/showroom

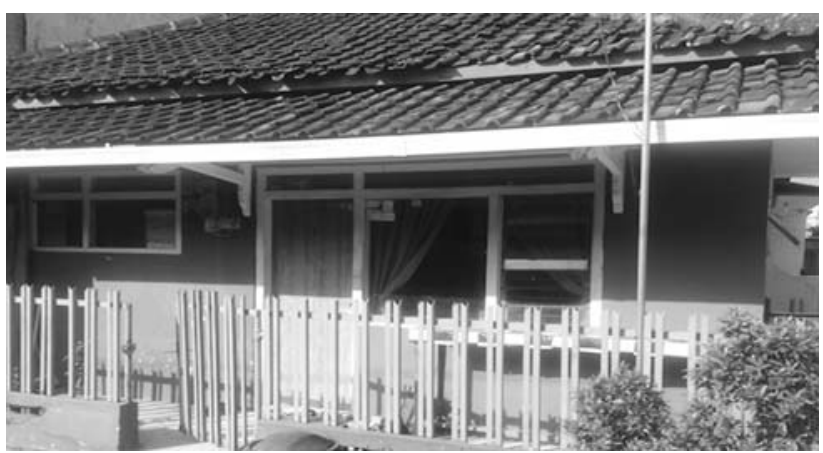

Hunian dengan tempat pengemasan/ packaging keripik tempe 


\section{Tipologi Fasad Hunian Pengrajin Tempe Koridor Jalan Sanan Malang \\ Rahadian Nugroho}

Perubahan yang dilakukan pada sebuah hunian dapat berbeda antara penghuni yang satu dengan yang lain walau dalam kawasan yang sama karena perubahan disesuaikan dengan kebutuhan penghuninya. Hal inipun terjadi pada hunian di Kampung Sanan. Sesuai gambar di atas maka jika dilihat secara fisik pada tampilan depan (fasad) hunian pembuat tempe mentah dan keripik tempe tidak ada perbedaan yang terlalu signifikan. Namun jika dibandingkan dengan hunian pembuat tempe dan keripik, maka akan terlihat perbedaannya. Apalagi jika dibandingkan dengan fasad hunian yang memiliki showroom/toko, perbedaannya semakin terlihat jelas. Sedangkan fasad hunian yang hanya mengemas (packaging) terlihat satu tingkat lebih baik dibandingkan hunian pembuat tempe mentah dan keripik tempe.

Jenis dan bahan pintu dari hunian pembuat tempe mentah dan hunian pengemasan terlihat sama. Namun dari kondisi fisik fasad sendiri terlihat jauh lebih terawat hunian yang pengemasan keripik tempe. Sedangkan bahan dan bentuk pintu dari hunian yang memiliki showroom cenderung identik dengan hunian pembuat tempe dan keripik tempe. Tampilan fasad keduanya juga memiliki kemiripan dari model rumah yang sedikit lebih modern dibandingkan tampilan fasad hunian lainnya. Komposisi variabel fasad bangunan masingmasing jenis pengrajin dapat dilihat lebih jelas dalam tabel di bawah ini.

\begin{tabular}{|c|l|l|l|l|l|}
\hline Variabel & $\begin{array}{l}\text { Produksi } \\
\text { tempe } \\
\text { mentah }\end{array}$ & $\begin{array}{l}\text { produksi keripik } \\
\text { tempe }\end{array}$ & $\begin{array}{l}\text { produksi tempe } \\
\text { dan keripik } \\
\text { tempe }\end{array}$ & $\begin{array}{l}\text { produksi tempe, } \\
\text { keripik tempe dan } \\
\text { membuka } \\
\text { toko/showroom }\end{array}$ & $\begin{array}{c}\text { pengemasan/ } \\
\text { packaging keripik } \\
\text { tempe }\end{array}$ \\
\hline Pintu & $\begin{array}{l}\text { Pintu model } \\
\text { lama dengan } \\
\text { bahan daun } \\
\text { pintu dari } \\
\text { kayu }\end{array}$ & $\begin{array}{l}\text { Pintu model } \\
\text { baru dengan } \\
\text { bahan daun } \\
\text { pintu kombinasi } \\
\text { dari kayu dan } \\
\text { sedikit kaca }\end{array}$ & $\begin{array}{l}\text { Pintu model } \\
\text { baru dengan } \\
\text { bahan daun } \\
\text { pintu kombinasi } \\
\text { dari kayu dan } \\
\text { sedikit kaca }\end{array}$ & $\begin{array}{l}\text { Pintu model baru } \\
\text { dengan bahan daun } \\
\text { pintu dari kaca dan } \\
\text { sedikit kayu }\end{array}$ & $\begin{array}{l}\text { Pintu model lama } \\
\text { dengan bahan } \\
\text { daun pintu dari } \\
\text { kayu }\end{array}$ \\
\hline Jendela & $\begin{array}{l}\text { Jendela } \\
\text { model } \\
\text { lama/nako } \\
\text { dengan } \\
\text { bahan kaca } \\
\text { biasa }\end{array}$ & $\begin{array}{l}\text { Jendela model } \\
\text { baru dengan } \\
\text { bahan kaca } \\
\text { biasa }\end{array}$ & $\begin{array}{l}\text { Jendela model } \\
\text { baru dengan } \\
\text { bahan kaca } \\
\text { rayband }\end{array}$ & $\begin{array}{l}\text { Jendela modern } \\
\text { dengan bahan kaca } \\
\text { rayband }\end{array}$ & $\begin{array}{l}\text { Jendela model } \\
\text { baru dengan } \\
\text { bahan kaca biasa }\end{array}$ \\
\hline Dinding \\
$\begin{array}{l}\text { Tidak terawat } \\
\text { dengan } \\
\text { permukaan } \\
\text { yang } \\
\text { terkelupas } \\
\text { terlihat batu } \\
\text { bata }\end{array}$ & $\begin{array}{l}\text { Tidak terawat } \\
\text { dengan } \\
\text { permukaan yang } \\
\text { pecah-pecah }\end{array}$ & $\begin{array}{l}\text { Terawat dengan } \\
\text { permukaan yang } \\
\text { sedikit pecah- } \\
\text { pecah }\end{array}$ & $\begin{array}{l}\text { Terawat dengan } \\
\text { permukaan cat yang } \\
\text { bagus }\end{array}$ & $\begin{array}{l}\text { Terawat dengan } \\
\text { permukaan yang } \\
\text { sedikit pecah- } \\
\text { pecah }\end{array}$ \\
\hline $\begin{array}{l}\text { Atap rendah } \\
\text { dengan } \\
\text { model atap } \\
\text { perisai }\end{array}$ & $\begin{array}{l}\text { Atap rendah } \\
\text { dengan model } \\
\text { atap perisai }\end{array}$ & $\begin{array}{l}\text { Atap tinggi } \\
\text { dengan model } \\
\text { atap perisai }\end{array}$ & $\begin{array}{l}\text { Atap tinggi dengan } \\
\text { model atap pelana }\end{array}$ & $\begin{array}{l}\text { Atap rendah } \\
\text { dengan model } \\
\text { atap perisai }\end{array}$ \\
\hline Atap & & & \\
\end{tabular}


Berdasarkan tabel di atas, dapat dikelompokkan klasifikasi hunian dari yang paling bagus ke yang paling buruk sebagai berikut:

1. Hunian dengan tempat produksi tempe, keripik tempe dan membuka toko/showroom.

2. Hunian dengan tempat produksi tempe dan keripik tempe.

3. Hunian dengan tempat pengemasan/packaging keripik tempe.

4. Hunian dengan tempat produksi keripik tempe.

5. Hunian dengan tempat produksi tempe mentah.

\section{KESIMPULAN}

Secara metodologi, untuk bisa merumuskan suatu tipologi arsitektur dalam arti klasifikasi dan pengelompokan bangunan berdasarkan tipe-tipe tertentu, maka harus dilakukan terlebih dahulu kajian tipologi pada satuan bangunan. Untuk kedua hal itu biasanya dipakai metode yang biasa dilakukan dalam sejarah, yang secara substansi mengikutsertakan aspek-aspek kebudayaan manusia (menyangkut norma dan religi, teknologi dan metoda membangun, sosial ekonomi, dan lainlain) sebagai faktor penyebab atau pengaruh perubahan bentuk arsitektur. Kajian tipologi dalam konteks definisi dan klasifikasi teori terdapat perbedaan dan kesamaan dari setiap teorinya. Kajian tersebut menjelaskan bahwa lingkup yang dibahas merupakan area makro, meso, dan mikro. Dari skala kawasan ynag dimunculkan oleh teori tersebut memberikan sebuah identitas atau ciri khas pada kawasan tersebut dalam skala makro, meso, dan mikro.

Objek komparasi sebagai pembanding penelitian agar mengetahui pembahasan yang terdapat pada penelitian yang sejenis. Dapat disimpulkan bahwa tipologi tidak terdapat pada skala tertentu akan tetapi dengan adanya teori sebelumnya dapat dibuktikan pembahasan tipologi membahas skala area makro, meso, dan mikro. Selain itu metode yang digunakan merupakan pendekatan kualitatif untuk melihat detail dan untuk mengambil data primernya.

Di kampung Tempe Sanan Malang, pada umumnya bangunan hunian yang memiliki toko/ showroom memiliki penampilan/fasad yang lebih baik dari hunian-hunian lainnya. Fasade lebih baik dikarenakan hunian-hunian tersebut terdapat toko/showroom terutama pada bagian depan. Apalagi jika letak hunian berada di pinggir jalan utama memungkinkan penghuni untuk mengubah bagian fasadenya dengan tujuan agar dapat menonjolkan produk keripik tempenya sehingga lebih menarik bagi pembeli untuk datang berkunjung ke tokonya. Hal ini diperkirakan berkaitan dengan persaingan usaha.

Pembuatan tempe dan keripik tempe termasuk salah satu jenis kegiatan industri karena kegiatannya mengolah bahan yang belum jadi menjadi produk yang memiliki nilai lebih tinggi dari pada sebelumnya. Industri tempe Dalam Lingkup Klasifikasi Baku Lapangan Usaha Indonesia (KBLUI) permbuatan keripik termasuk kategori Industri makanan dari kedele dan kacang-kacangan lainnya Bukan kecap, tempe dan tahu berada di pengawasan Direktorat Jendral Industri Argo dan Kimia. Kebijakan pemerintah terhadap sebuah kawasan hanyalah untuk sebagai dasar atau standar sebuah perencanaan dan perancangan sebuah permukiman untuk membuat sebuah kawasan lebih dikenal identitasnya atau ciri khas kawasan tersebut, karena kawasan menentukan kualitas dan untuk mengkontrol pola ruang kota.

\section{Daftar Pustaka}

Habraken, N. J. (1998), The Structure of The Ordinary : Form and Control in the Built Environment, The MIT Press, Massachusetts.

Krier, R. 1988. Architectural Composition. London: Academy Edition. 


\section{Tipologi Fasad Hunian Pengrajin Tempe Koridor Jalan Sanan Malang \\ Rahadian Nugroho}

Lynch, Kevin. 1969. The Image of The City. Cambridge, Massachusetts: MIT Press.

Lippsmeier, G. 1980. Bangunan Tropis (Edisi ke-2). Jakarta: Erlangga

Markus, Zahnd. 1999. Perancangan Kota Secara Terpadu. Yogyakarta: Kanisius.

Turner, J. F. C. (1972), Freedom to Build, Dweller Control of Housing Process, The Mac million Co, New York.

Shurtleff, W., and Aoyagi, A. 2007. History of fermented soymilk and its products. Soy Info Center Layafette, California.
Shirvani, Hamid. 1985. The Urban Design Process. Van Nostrand Reinhold Company. New York.

Sartini, 2004. Menggali Kearifan Lokal Nusantara Sebagai Kajian Filsafat. Jurnal Filsafat. Jilid 37, Nomor 2 hal. 111-120. http://dgi-indonesia.com/ wp-content [Diakses 8 September 2001.

Wiranto. 1999. Arsitektur Vernakular Indonesia. Dimensi Teknik Arsitektur. Volume 27, Nomor 2: 15-20. 